\title{
ДРЕВНЕТЮРКСКИЕ РУНИЧЕСКИЕ НАДПИСИ И ИХ АРХЕОЛОГИЧЕСКИЕ КОНТЕКСТЫ В ГОРАХ КУЛЖАБАСЫ
}

\author{
(C) 2018 г. А.Е. Рогожинский, В.В. Тишин
}

\begin{abstract}
В статье дается новая попытка прочтения древнетюркских рунических надписей Кулжабасы I и II, а также обсуждаются возможности их датировки и атрибуции на основе комплексного анализа имеющихся данных. Авторами анализируются особенности надписей и археологический контекст их обнаружения. Предпринята попытка выделить особенности графического фонда надписей Кулжабасы в общем контексте памятников древнетюркской рунической письменности азиатского ареала. В составе археологического ландшафта гор Кулжабасы обе рунические надписи локализуются в двух обособленных районах концентрации средневековых памятников (зимних стоянок кочевников, могильников, ритуальных оград с изваяниями, петроглифов «престижной» тематики), вблизи крупных стоянок, отмеченных наскальными изображениями однотипных знаков (тамга). Археологический контекст Кулжабасы I позволяет датировать надпись не ранее второй половины VIII в. или IX-X вв. Предполагается принадлежность знаков идентичности одного типа (тамги №№ 1 и 4) племенному объединению карлуков.
\end{abstract}

Ключевые слова: археология, Жетысу, древнетюркские рунические надписи, археологический контекст, тамга, петроглифы, карлуки

В последнее десятилетие заметен рост публикаций новых находок древнетюркских рунических текстов, происходящих с территории Казахстана, а также специальных работ, посвященных их прочтению и историко-филологической интерпретации. Темпы продолжающихся полевых изысканий не снижаются, и фонд памятников рунической письменности пополняется новыми материалами, создавая предпосылки для издания сводных работ - первых в казахстанской историографии [Базылхан, 2013; Bazilkhan, 2014]. В то же время накопление поискового опыта и совершенствование технологии документирования рунических граф- фити неизбежно побуждает специалистов возвращаться к уже известным памятникам для детализации и уточнения первичных наблюдений, способствуя одновременно углубленному изучению археологического окружения эпиграфических текстов, выяснению их места в локальном ландшафте. Данная статья есть опыт совместного возвращения археолога и востоковеда-тюрколога к двум памятникам, открытым ранее и не раз уже привлекавшим внимание разных исследователей, - руническим наскальным надписям Кулжабасы I и II в одноименных горах Шу-Илейского междуречья. 


\section{Кулжабасы I}

Местонахождение и описание. Жамбылская область, Кордайский р-н, в 30 км к северо-западу от ст. Отар; Шу-Илейские горы, южные склоны гор Кулжабасы, ущелье Жаксылыксай, или долина № 3 по принятой нумерации комплекса [Сала, Деом, 2005, рис. 7.1]. Надписи Кулжабасы I (Жаксылыксай I-III, по И.Л. Кызласову [Рогожинский, Кызласов, 2011, c. 330-331]) обнаружены в 2009 г. и опубликованы одним из авторов [Рогожинский, 2010, с. 333-334, рис. 3, 2, 3]. В последующие годы памятник неоднократно дополнительно обследовался А.Е. Рогожинским и документировался. К сожалению, предыдущие прочтения текста, предложенные разными исследователями [Базылхан, 2013, с. 99-100; Bazilkhan, 2014, s. 5-6; Тишин, 2015; 2017, c. 249-252], вынужденно основывались на первичной прорисовке надписи, как оказалось, неточно воспроизводившей ряд рунических знаков одной из строк. Здесь мы публикуем уточненную копию надписи и фотографии памятника (рис. 1; 2).

Надпись нанесена на вертикальную поверхность скалы, ориентированную на запад. У верхнего края, на высоте 1,5 м от подножия скалы, техникой протирки выполнено крупное изображение тамги № 1 в форме V-образной фигуры (30 cм) с двумя отходящими влево короткими линиями. Слева от нее и ниже находятся три вертикальные рунические строки.

Знаки прорезаны острым металлическим инструментом; линии тонкие, неглубокие; высота колеблется от 2-3 до 5 см. Нижняя строка (12 см) состоит из 7 знаков (стк. 1); она занимает не патинированный участок скалы и имеет светлый оттенок. Выше нее вдоль края выступа скалы, слева от тамги, прорезана самая длинная строка (36 см), состоящая из 16 или 17 знаков (стк. 2). Знаки следуют один за другим с примерно равным интервалом и одинаковым отступом от края грани скалы. В средней части надпись разделяет неширокая трещина, за которой строка отклоняется влево, повторяя изгиб выступающей поверхности. Цвет знаков соответствует светло-коричневой патине, покрывающей тамгу № 1 . В $15 \mathrm{~cm}$ справа расположена третья строка (стк. 3) длиной 4,5 см; она состоит из двух знаков, развернутых основанием вправо; цвет патины, как у тамги № 1.

Порядок расположения графитти позволяет считать, что рунические строки создавались после нанесения на скалу тамги № 1 . Начальные знаки стк. 2 и 3 находятся на одном уровне, на одинаковой высоте от подножия скалы, и по физическим параметрам (высота, глубина и ширина линий) знаки обеих строк весьма похожи. Знаки стк. 1 имеют иные пропорции, и сама строка зримо отделена от стк. 2, хотя вписана с ней в единую вертикаль. Возможно, стк. 1 нанесена на скалу после стк. 2 и 3.

На соседней справа грани скалы в технике выбивки и протирки выполнена тамга № 2 в форме змеи (40 см). При фронтальном обзоре панно тамги №№ 1 и 2 выглядят соразмерными, но тамга-змея занимает более высокую позицию (рис. 1, 1). Левее и выше скалы с тамгами находится плоскость с изображениями всадников-знаменосцев.

Ложе горной долины занимают остатки средневековой стоянки, у скалы с тамгами и надписями заметны руины каменных построек; найдены фрагменты стеклянной, керамической 
Рогожсинский A.E., Тишин B.B. Древнетюркские рунические надписи и их археологические...
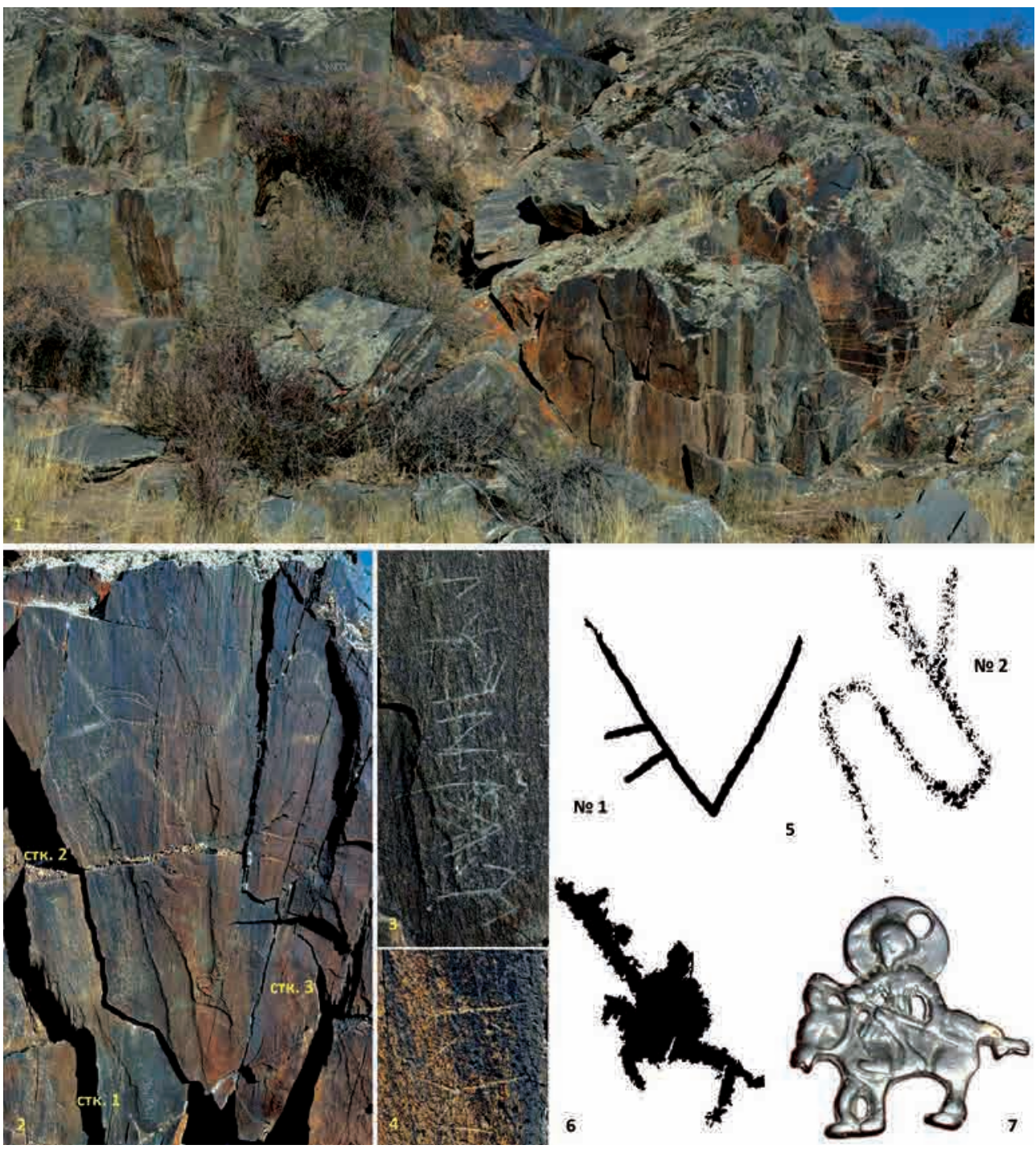

Рис. 1. Кулжабасы, долина 3. 1-место расположения надписи Кулжабасы I; 2 - расположение тамги № 1 и трех строк надписи; 3 -строка 1; 4 - строка 3; 5 - тамги №№ 1 и 2; 6 - наскальное изображение всадника; 7 - Блямка с изображением всадника [по: Борисенко, Худяков, 2008].

Fig. 1. Kuljabasy, valley 3. 1 - the location of the inscription Kuljabasy I;

2 - the location of the tamga no. 1 and the three lines of the inscription; 3 -line 1; 4 - line 3; 5 -tamga №oo 1 and 2; 6-rock art of the rider; 7 -plaque with the image of a rider (by: [Borisenko, Khudyakov, 2008])

гончарной и лепной посуды, трехлопастная бляшка-накладка [Рогожинский, 2010, рис. 3, 1]. По мнению А.И. Торгоева, любезно сообщенному А.Е. Рогожинскому, тройник с фигурными лопастями отличается рядом признаков, не характерных для дан- ного типа изделий IX-X вв., но имеет близкие аналогии в материалах из мог. Часовенная гора на Енисее [Гаврилова, 1965 , с. $73-74$, рис. 13, 15], из слоя пожара нач. ХІІІ в. на Краснореченском городище и в целом относится «К позднекараханидской или 

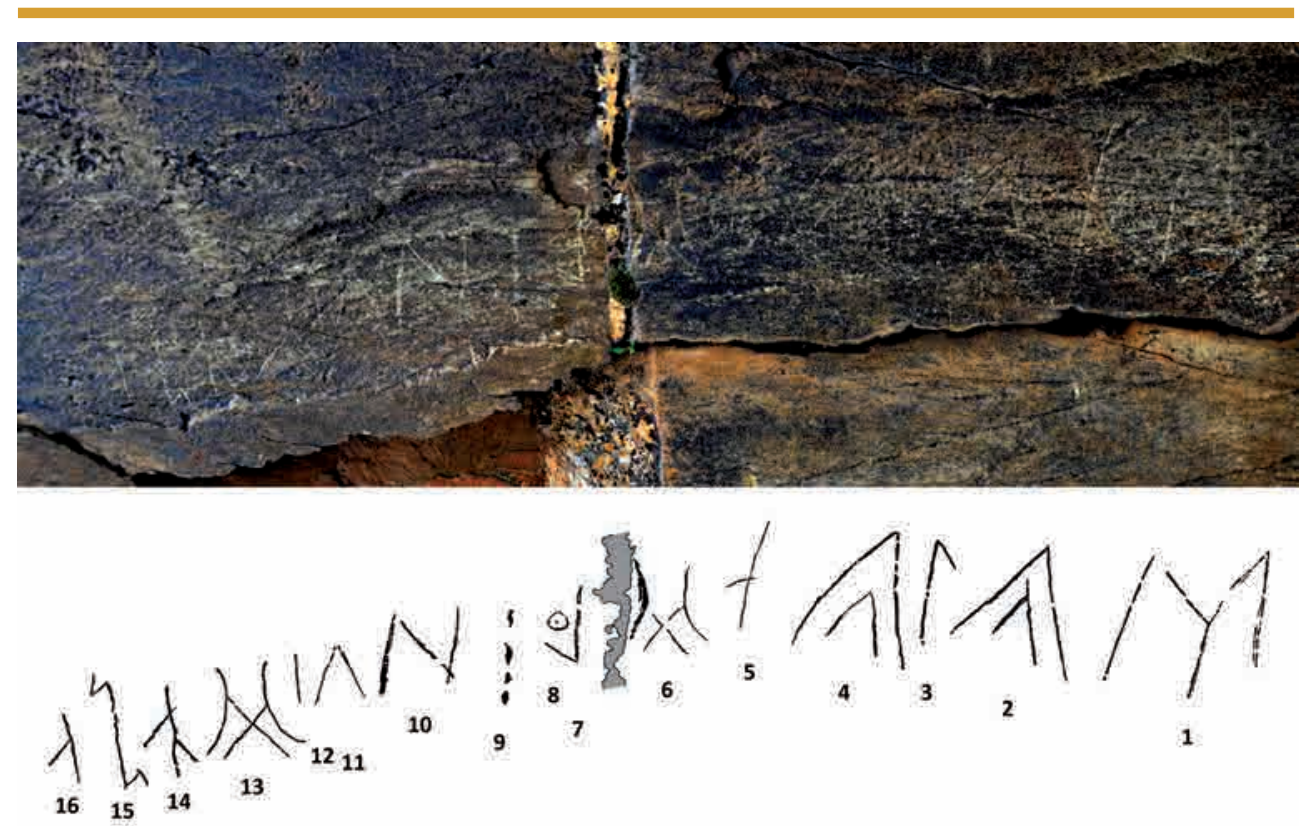

Рис. 2. Кулжсабасы I, строка 2. Фото и прорисовка А.Е. Рогожинского, 2018 г. Fig. 2. Kuljabasy I, line 2. Photo and drawing by A.E. Rogozhinskiy, 2018

уже раннемонгольской группе» предметов. Образцы столовой посуды со стоянки, по мнению В.А. Кольченко и А.А. Нуржанова (устная консультация), находят сходство с керамическим комплексом X-XI вв. и, возможно, IX в. городищ Шуйской долины (Красная речка, Новопокровское) и Кастек в Шу-Илейском междуречье. В целом, комплекс находок не типичен для рядовых стоянок средневековых кочевников этого района.

Некоторые основания для датировки археологического окружения надписей Кулжабасы I дает упомянутая композиция с изображениями знаменосцев. Гравюры сопоставимы с металлическими бляшками (рис. 1, 6, 7), изображающими панцирных всадников с дисками (щитами) за спиной, которые «обнаружены на территории распространения культур енисейских кыргызов и кимаков и были характерны для их торевтики в IX-X вв.» [Борисенко, Худяков, 2007, с. 90 , рис. 2 ,
2; 4, 1, 2]. Как показало недавнее исследование [Касанов и др., 2017, c. 115-133], изображения всадников со знаменами, являясь знаковым образом наскального искусства тюркской эпохи, встречаются отнюдь не повсеместно. Изображения знамен и знаменосцев входят в ограниченный круг «престижных» гравюр-маркеров, создававшихся в особо значимых местах и часто - вблизи крупных стоянок, устроенных в наиболее благоприятных для обитания условиях.

В составе комплекса Кулжабасы долина 3 и близлежащие ущелья занимают особое положение: в этом районе зафиксировано множество разновременных крупных стоянок, курганных могильников, ритуальных оград (одна с лицевой стелой, отмеченной тамгой) и средневековых петроглифов. Именно здесь сосредоточено наибольшее количество лучших гравюр тюркской эпохи, включая изображения знаменосцев (долины 2 и 3). 
Рогожинский A.E., Тишин B.B. Древнетюркские рунические надписи и их археологические...

Прочтение и интерпретациия надписи Кулжабасы I. Уточненная документация памятника вносит изменения только в стк. 2 (рис. 2); первоначальное воспроизведение знаков стк. 1 и 3 подтверждается.

\section{Текст:}

(1) SY ${ }_{5} \mathrm{~N} \hat{\wedge} \uparrow$

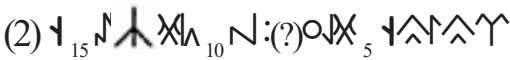

(3) $\Upsilon \times$

транслитерация: (1) $\mathrm{r}^{2} \mathrm{t}^{1} \mathrm{Iqk}$ $\breve{\mathrm{s}}^{1} \mathrm{~A}(2) \mathrm{r}^{2} \mathrm{t}^{1} \mathrm{It}^{1} \mathrm{D}_{5} \gamma \| 1^{1} \mathrm{M}(?): \mathrm{q}_{10}$ S s ${ }^{2} \gamma \underline{I C}(?) n^{2}{ }_{15} \mathrm{D}(3) \mathrm{d}^{2} \mathrm{r}^{2}$

Транскрипция: (1) (ä)r (a)tï (a) q k(e)š a (2) (ä)r (a)tï t(a)y $\gamma(i) 1 ~ m$ ? : q(a)ś s(a)yïč n(ä)n (вар.: (e)n(i)y / (e) $\mathrm{n}(\ddot{a}) \mathrm{y})(3)(\mathrm{e}) \mathrm{d}(\ddot{a}) \mathrm{r}$

Перевод: (1) имя мужа-воина Ак Кеш (букв. 'белый колчан'); (2) имя мужа-воина Тангыл; (надежного) сто́рожа границы удел (вар.: '(надежного) сто́рожа границы метка твоя' / '(надежный) сторож границы, ты сделай метку') (3) иди (следуй)!

\section{Комментарий.}

är atï: стандартная для памятников древнетюркской рунической письменности формула, обозначающая 'имя мужа-воина'.

aq keš: судя по всему, прочтение этого сочетания может считаться достаточно достоверным, исходя из того, что следующий знак, обозначающий широкий неогубленный гласный, имеет скорее пунктуационное значение [Васильев, 1983, с. 46, 50; Alimov, 2014, s. 26, No 39] (см. также: [Кызласов, 2012, с. 40-41]).

är atï: вновь стандартная формула со значением 'имя мужа-воина'.

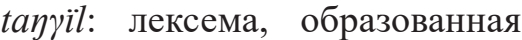
при помощи аффикса $+G I l$, образующего цветовые оттенки, исходя из значения, содержащегося в производящей основе, или аффикса $+G X l$, среди прочих также имеющего функцию образования названий животных, в основе которых лежат наименования какой-либо части тела, но сам аффикс добавляет семантику белизны [Erdal, 1991, vol. I, p. 97-98, 99]. И для того, и для другого объяснения может быть использован пример зафиксированного в кыргызском языке слова таң 'белое пятно ниже хвоста, под хвостом $(y$ некоторых животных)' [Киргизскорусский словарь, 1985, с. 203].

Сложно найти объяснение с точки зрения грамматики для интерпретации знака в виде кружка, который имеет относительно небольшие размеры и фактически примыкает к знаку $/ 1 \%$. Допустимо предполагать, что он не имеет отношения к надписи. Знак отчетливо виден, но существенно отличается от остальных графем незначительной глубиной линий, фактически царапин на поверхности скалы. После него начертан словоразделитель, состоящий из нескольких точек.

$q a s ́:$ здесь допустимо видетьслово qaš в значении 'край, берег, бровка, граница' [Древнетюркский словарь, 1969, с. 431], 'the side, edge, summit' [Clauson, 1972, р. 669], являющееся, очевидно, вторичным после 'бровь' [Этимологический словарь, 1997, c. 343-345]. Достоверно это значение фиксируется впервые в памятниках караханидско-уйгурского языка. Так,

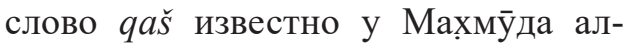
Кāшгарū как 'herhanği bir şeyin kıyısı' [Divanü, 1985, c. III, s. 152], «'the side, edge, summit', etc. (harf ... wa šafiruhu) of anything» [Clauson, 1972, p. 542], 'the edge or rim' [Maḥmūd al-Kāšyarī, 1984, s. 226], 'край, конец чего-либо' [Махммӯд ал-К̆а̄шгарӣ, 2005, с. 853].

Вероятно, однако, оно присутствует в одной из надписей Кочкорской долины (надпись № 4) [Кляшторный, 2003, с. 296; 2006, с. 356] 
(см. иначе: [Alimov, 2003, s. 20-21; Alimov, 2014, s. 168-169; Y1ldirim et al, 2013, s. 306]).

sayï̌: чтение предположительно, в том числе из-за сложности интерпретации последнего знака. Слово можно сравнить с зафиксированной в Четвертой Таласской надписи (стк. 1) лексемой $s^{1}(a) \gamma c$-ïg (вин. пад.), которую Р. Алимов трактует как 'muhafiz', 'maiyet' [Alimov, 2014, s. 18, 92-93, 94, 96, 97], предполагая здесь отсутствие одной буквы, что подразуме-

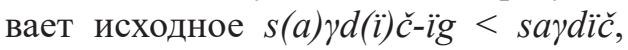
зафиксированное еще в четырех таласских надписях (Тал 2, стк. 1: $s(a)$

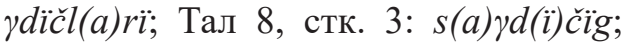

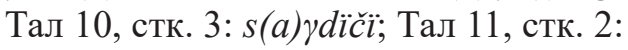

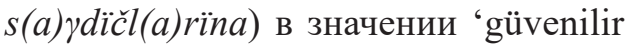
kimse, muhafiz' [Alimov, 2014, s. 66, $68,111,122,123,126,128,186]$, затем встречающееся уже у Махмӯда алК̆̄̄шгарӣ в значении al-sadīq 'a true friend' [Clauson, 1972, p. 806]. Слово восходит к sar 'здоровый, верный', по-видимому, гетерогенному омониму со значением 'правый' [Этимологический словарь, 2003, с. 134$136],++d I$, аффикс, образующий наречия от прилагательных [Erdal, 2004, p. 330], $++(X) \check{c}$, показатель диминутива [Erdal, 1991, vol. I, p. 44-47].

Начиная с караханидскоуйгурского времени в текстах встречается также слово saqč 'сторож, хранитель' [Радлов, 1911, стб. 257; Древнетюркский словарь, 1969 , c. 486], 'guard, guardian' [Clauson, 1972 , p. 806], восходящее к $s a q$ 'внимательный, чуткий, настороженный’, 'осторожный' и т.д. [Радлов, 1911, стб. 239-240; Древнетюркский словарь, 1969, с. 485-486; Этимологический словарь, 2003, с. 156-158], "'awake, alert', and the like» [Clauson, 1972 , p. 803]. Здесь заманчиво допустить какую-то контаминацию двух основ, $s a \gamma$ и $s a q$, что в нашем случае, как и в Четвертой Таласской надписи, позволило бы прочитать даже *saүči и предположить самостоятельное происхождение этой формы. Однако известные на основе языкового материала примеры контаминации двух основ показывают именно распространение слова $s a q$ в том же значении, что и $s a \gamma$ в его фонетических вариантах (каз. сау, кырг. соо и др.), и, соответственно, их равноценное использование, но не наоборот [Радлов, 1911, с. 233, 239-240, 259-260; Киргизско-русский словарь, 1985 , c. 124; Этимологический словарь, 2003, c. 158].

nӓэ: судя по тому, что слово находится в конце фразы, из двух значений лексемы, известных по тюркоязычным памятникам, следует принять его трактовку как имени существительного, обозначающего 'вещь, предмет, дело; нечто’, или конкретнее 'вещи, имущество, богатство, средства существования', что фиксируется в караханидско-уйгурских текстах [Радлов, 1905, стб. 666-667; Древнетюркский словарь, 1969, с. 358; Clauson, 1972, p. 778]. Именно как al-māl 'property, wealth' слово переводится в стихе, приводимом в словаре Махмӯда ал-К̄āшгарӣ, а в Ферганском списке «Кутадгу билиг» это арабское слово стоит в тех контекстах, где в Гератском и Каирском списках написано näy [Mert, 2017, s. 201, 204]. Мы переводим на русский язык при помощи слова 'удел', подразумевая абстрактное значение.

С другой стороны, здесь возможно предположить чтение en-iy или епӥ- $\eta$.

Тогда в обоих случаях речь будет идти об известной основе *en-, впервые достоверно фиксирующейся в составе глагола епӓ- 'метить' у 
Рогожинский A.E., Тишин B.B. Древнетюркские рунические надписи и их археологические...

Махммуда ал-К̄̄шгарӣ, но, вероятно, также и в памятниках древнетюркской письменности в общем значении какой-то метки или знака (см. дискуссию в кн.: [Тишин, 2018, с. 104105]).

При чтении рассматриваемого слова в тексте Кулжабасы I мы находим его с показателем принадлежности 2 лица ед. ч. + $(X) \eta$, либо здесь глагол епӓ- с аффиксом повелительного наклонения 2 лица ед. ч. $-(X) \eta$, зарегистрированного в памятниках древнетюркской рунической письменности в контекстах с адресантами как единственного, так и множественного числа [Erdal, 2004, p. 236-237, 520].

edär: форма (j)edär- 'искать, гнаться, идти следом’ [Древнетюркский словарь, 1969 , c. 162, 164], «'to pursue ', primarily in the sense of chasing game or pursuing an enemy; hence more vaguely 'to follow'» [Clauson, 1972, p. 67] (cp.: [Erdal, 1991, vol. I, p. 115, 310; vol. II, p. 771-772]), в неоформленном повелительном наклонении, что свидетельствует об обращении к объекту в единственном числе.

Замечания $\kappa$ графическому фонду. Памятник тесно примыкает к надписям Таласской и Кочкорской долин, о чем говорят, прежде всего, начертания знака /q/ [Alimov, 2014, s. 25, No. 18]. Начертание $/ \gamma /$ кроме них сближает его с алтайскими надписями [Alimov, 2014, s. 25, No. 16]. Начертание $/ \mathrm{n}^{2} /$ близко к таковому в надписях из местности Ак-Олён [Alimov, 2014, s. 25, No. 15]. Начертание первого знака стк. 2, $/ \mathrm{r}^{2} /$ как по дукту, так и пропорциям элементов, в частности длинных боковых отводов, также сближает написание с аналогичными знаками из местности Ак-Олён [Alimov, 2014, s. 26, No. 30].
Необычная форма шестого знака стк. 1 в форме направленной вверх «птичьей лапы», который мы читаем как /క̌s, в енисейских надписях

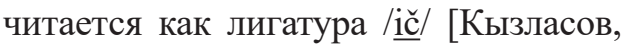
1994 , с. 89, 91; Кормушин, 1997, с. 163 , $167 ; 2008$, с. 52, 55, 56]; он характерен также для алтайских надписей и турфанских документов на бумаге, где читается как/ $/ 2$ / [Васильев, 1983, с. 136, табл. 26, стк. 15]. В отдельных текстах с территории Алтая он также читается как / $\breve{\mathbf{s}}^{1} /$ [Кызласов, 2003, с. 13].

Четырнадцатый знак стк. 2, интерпретированный нами как лига-

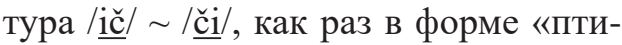
чьей лапы», известен по орхонским и енисейским памятникам [Tekin, 1968 , p. 22, note 1, p. 24, 31, 45; Tuna, 1994, s. 212-213; Alimov, 2014, s. 27, No. 46], чаще рассматриваясь здесь как аллограф предыдущего знака.

Одиннадцатый знак стк. 2, в форме «крыши», для которого предполагается значение веляризованного шипящего сибилянта / ̌s/, широко распространен в енисейских памятниках, а также встречается в текстах с территории Алтая и Таласской долины, по большей части употребляясь в палатальном ряду [Васильев, 1983 , с. 133 , табл. 25 , стк. 2-4, с. 135 , табл. 26, стк. 2, 3; Alimov, 2014, s. 25, No. 24].

Замечательной характеристикой является направление вниз штамба у /y/, встречающееся в нескольких енисейских текстах и одном рукописном турфанском документе [Васильев, 1983 , с. 126 , табл. 20 , стк. 11].

Замечания к датировке и атрибуцчии. В предлагаемом варианте чтения текст выглядит чрезвычайно бедным с точки зрения синтаксиса. Единственный глагол, составляющий при этом самостоятельную конструкцию (стк. 3), не имеет никаких 
дополнительных показателей. За исключением выражения $\ddot{a} r a t \ddot{i}$, другие сочетания слов также не содержат никаких грамматических показателей, хотя, например, во второй части фразы в стк. 2 при любом из предложенных вариантов прочтения они кажутся необходимыми, поскольку позволили бы четче разграничить отношения между лексемами.

Следует отметить четкое функциональное распределение графем, обозначающих сибилянты, хотя, безусловно, материал недостаточно репрезентативен в количественном отношении.

Некоторые замечания могут быть сделаны в отношении лексического фонда, опять же при учете возможности перепрочтения текста. Отдельные лексические единицы в тех значениях, которые могут быть предложены для их интерпретации исходя из контекста, находят параллели только в текстах среднетюркского периода, т.е. начиная с караханидскоуйгурского времени. Это касается как предполагаемого слова qaš в значении 'граница', так и пӓ̈ в его синтаксической функции. Впрочем, какихлибо специфических характеристик текста, позволяющих рассуждать о косвенных датировках, выделить не представляется возможным. Сам текст, если он прочитан правильно, представляет собой типичную «посетительскую» надпись.

\section{Кулжабасы II}

Местонахождение и описание. Жамбылская область, Кордайский р-н, в 25 км к северо-западу от ст. Отар; Шу-Илейские горы, горы Кулжабасы, долина 14. Надпись обнаружена в 2012 г. археологом Б.А. Железняковым и Л. Херманном. Ранее предложенные прочтения основывались на фотографиях и прорисовке знаков, выполненной по снимкам авторов открытия Н. Базылханом [Железняков и др., 2013, с. 149-150; Базылхан, 2013, c. 101-102; Bazilkhan, 2014, s. 8-9; Тишин, 2017, с. 253-256]. Позже памятник обследован А.Е. Рогожинским; здесь публикуются документальные материалы, уточняющие облик отдельных графем (рис. 4).

Долина 14 расположена в средней части гор Кулжабасы; в трех смежных долинах 12-14 насчитывается около 20 стоянок XIX - начала $\mathrm{XX}$ в., многие из которых, судя по находкам керамики разного облика, осваивались кочевниками I тыс. до н.э. - I тыс. н.э. и в эпоху бронзы. Обилие выразительных петроглифов тюркского времени тоже выделяет этот район Кулжабасы. Наряду с участком, изобилующим средневековыми петроглифами и стоянками в долинах 3-6, он образует вторую зону наибольшей концентрации памятников тюркской культуры [Sala, Deom, 2016 , s. 80-81, graph. 2, 3, pic. 01, 03, 04], в том числе рунической письменности.

В нижней части долины находятся руины одной из крупных казахских зимовок начала XX в. На окружающих скалах есть петроглифы разного возраста и арабографичная надпись, прочтение которой выполнено Н. Базылханом [Базылхан и др., 2013, с. 153, рис. 1]. Примечательны средневековые изображения животных в сходной манере (рис. 3,3 ). На правом берегу долины отмечены остатки средневековой стоянки; над площадкой на вертикальной скале выбиты две тамги: № 3 в виде извивающейся змеи и № 4 в форме уголка с окружностью между расходящимися лучами (рис. $3,1,2)$. Тамги крупных размеров (25 и 18 см), выбиты глубоко на шероховатой поверхности камня. Вопросы датировки и этно- 
Рогожсинский A.E., Тишин B.B. Древнетюркские рунические надписи и их археологические...

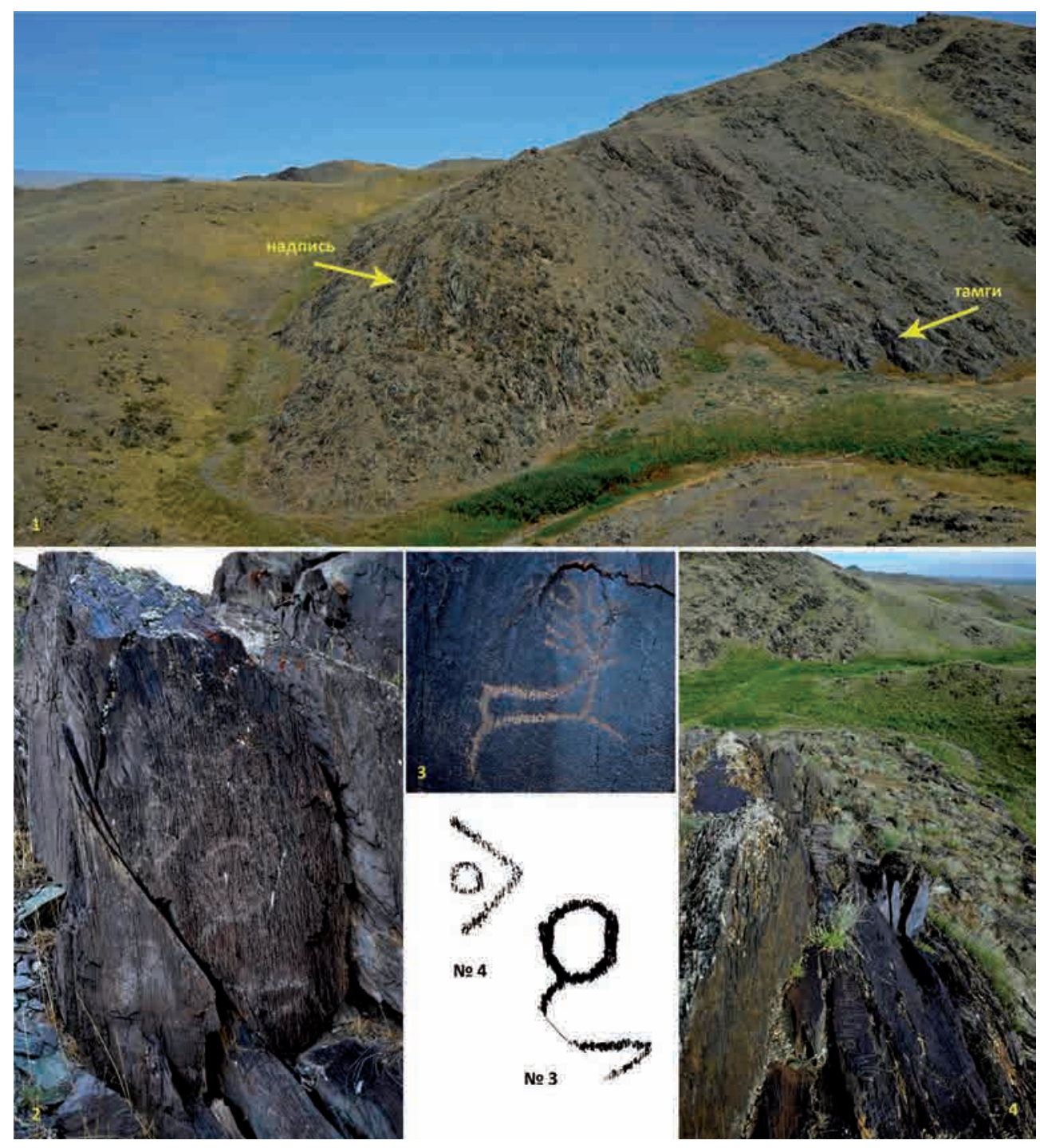

Рис. 3. Кулжабасы, долина 14. 1, 4-место расположения надписи Кулжабасы II; 2 - тамги №№ 3 и 4; 3 - изображение оленя

Fig. 3. Kuljabasy, valley 14. 1, 4-the location of the inscription Kuljabasy II; 2 - tamga №oo 3 and 4; 3 - image of a deer

политической атрибуции знаков данного типа уже рассматривались одним из авторов [Рогожинский, 2016, c. 59-60]. Для тамги № 4 (имеет 5-6 разновидностей, в том числе, как тамга № 1) установлен основной ареал, включающий области Жетысу и Алтая, и высказано предположение о ее связи с карлукским объединением; обоснована датировка этой группы знаков для Жетысу в интервале второй половины VIII/IX-X вв. Недавно отождествление подобных знаков с карлуками поддержано исследованием собрания знаков на Калбак-Таш I [Кубарев, 2018, с. 35-36]. 
На южном склоне того же увала, где обнаружены тамги, сконцентрировано наибольшее количество петроглифов долины, включая ряд импозантных картин, описанных нашими предшественниками [Железняков и др., 2013, с. 148-149, рис. 3]. Значительная часть древних петроглифов подновлена в средние века, о чем позволяет судить сходный цвет патины рунической надписи Кулжабасы II, расположенной здесь же на горизонтальной поверхности в верхней части массива (рис. 3, 4). Плоскость вплотную прилегает к отвесной скале высотой ок. 1 м и имеет доступ только с южной стороны, т.е. писавший и читающий текст на месте обращен лицом к северу. Заметить надпись можно лишь вблизи. Строка из 18 знаков нанесена на узкую грань песчаника, покрытую черной патиной. Знаки выполнены неглубокой выбивкой и выделяются коричневым оттенком патины. Общая длина строки 78 см, высота знаков до 10-11 см.

Прочтение и интерпретация надписи Кулжсабасы II. Несмотря на то что рунические знаки на представленных фотоснимках просматриваются достаточно хорошо (рис. 4), интерпретация некоторых из них вызывает сложности. Наибольшие трудности возникают в связи с интерпретацией 3-го и 15-го знаков, данных соответственно в форме ромба и «кружка». Если сближать их с таласскими надписями, то для обоих допустимо предполагать фонемное значение /m/ [Батманов, 1971, с. 28; Васильев, 1983, с. 123,125 , табл. 18 , стк. $19,37-40$; Alimov, 2014, s. 24, №. 8]. Принимая такое фонемное значение знаков, в транслитерации мы условно обозначаем их соответственно $M_{1}$ и $M_{2}$.

\section{Текст:}

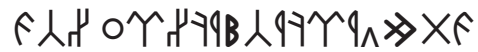

транслитерация: $\mathrm{gd}^{2} \mathrm{M}_{1} \dot{S}^{2}{ }_{5}$

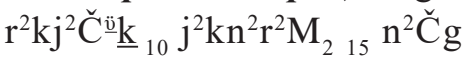

Транскрипция: (ä)g(i)dm ${ }_{1}(\mathrm{i}) \mathrm{s}$ $\mathrm{j}(\mathrm{e}) \mathrm{rk}(\mathrm{a}) \mathrm{j}$ čökj(ä)k(i)n (ä)r(i)m $\mathrm{m}_{2}$ (e) nč(i)g

Перевод 'склонившийся, возненавидит (проклянет? вар.: отвергнет) то, перед чем (вар.: того, перед кем) преклоняет колени, [и] моего мужавоина (вар.: меня, мужа-воина), [то есть] того, кто поставил метку'.

\section{Комментарий}

ägid-miś: форма причастия абсолютного прошедшего времени от

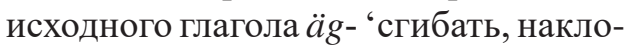
нять' [Древнетюркский словарь 1968, c. 165; Clauson, 1972, p. 99-100] c аффиксом - $(X) d$-, образующим медиальные формы со значением состояния или активности [Erdal, 1991, vol. II, p. 642-644]. Здесь, по-видимому, форма на -mIš выступает в субстантивированной форме, обозначая неочевидное прошедшее время и указывая производителя действия, в субстантивированной форме, и выполняет функцию подлежащего [Erdal, 2004, p. 297-299; Кормушин, 2008, с. 227]. Формально в данном случае возможны две трактовки рассматриваемой формы: либо форма на $-m I \check{s}$ выступает в надписи в предикативной или атрибутивной функции, либо является подлежащим. Второй вариант более вероятен, учитывая дальнейшее содержание текста.

jer-käj: глагол je:r- 'пренебрегать, отвергать, питать отвращение', 'поносить, хулить' [Древнетюркский словарь 1968, с. 257], 'to loathe (something, esp. food, Acc.); to criticize, or blame (someone Acc.)' [Clauson, 1972, p. 955], + -GAj- аффикс абсолютного будущего времени, иногда употреб- 
Рогожсинский A.E., Тишин B.B. Древнетюркские рунические надписи и их археологические...
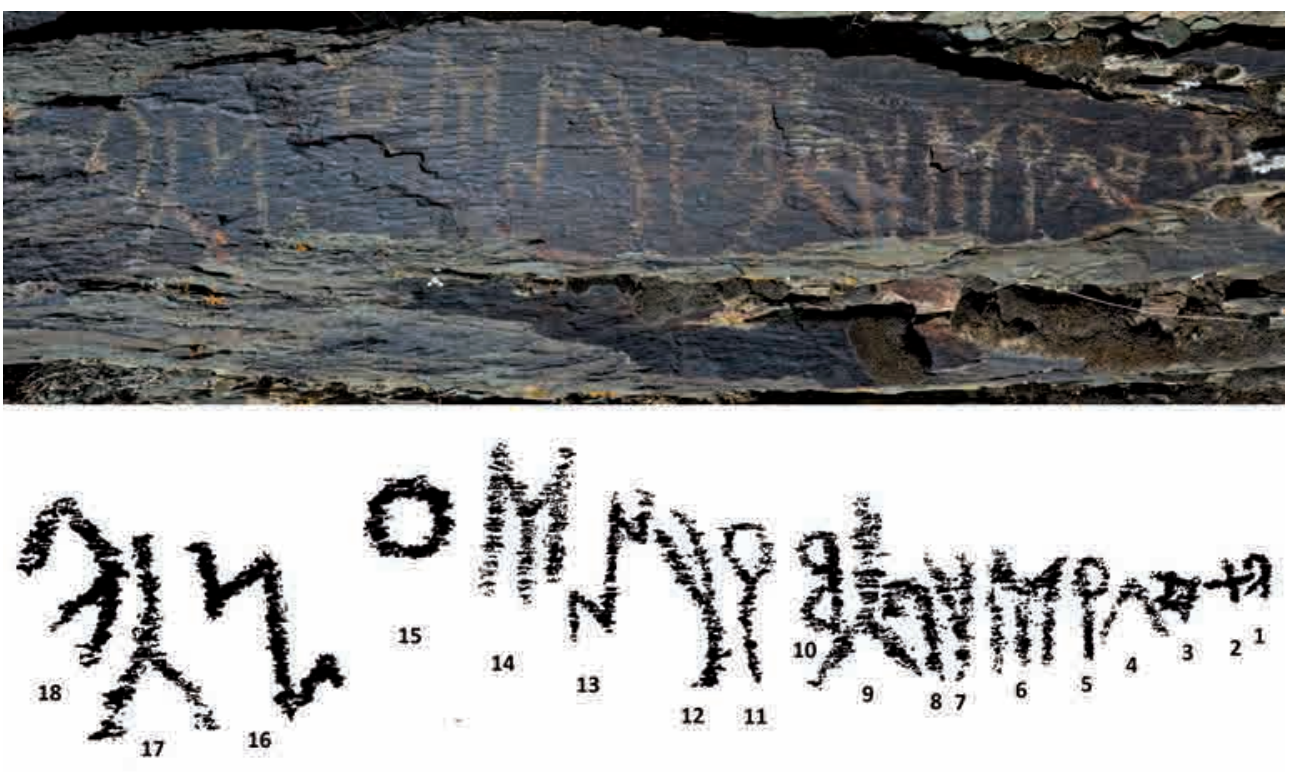

Рис. 4. Кулжабасы II. Фото и прорисовка А.Е. Рогожинского, 2018 г.

Fig. 4. Kuljabasy II. Photo and drawing by A.E. Rogozhinskiy, 2018

ляющийся в модальном значении возможности или долженствования действия. Последний неизвестен для орхонских памятников, однако фиксируется в Карабалгасунской надписи и далее в енисейских текстах [Erdal, 2004, p. 242-244]. Употребление формы на $-m I \check{s}$ в сочетании с формой на $-G A j$ зафиксировано лишь в контексте со служебными глаголами $\ddot{a} r-$ и bol-, позволяющими обозначить будущее совершенное время [Erdal, 2004, p. 270, 272].

čökjäk-in: глагол čök- 'опускаться, становиться на колени', 'прям. и перен. опускаться, падать' [Древнетюркский словарь, 1968, с. 154], «'to kneel down', esp. of a camel, but also of human beings, and more vaguely 'to sink, subside, collapse', and the like» [Clauson, 1972, p. 413-414] +*-(X)jAK - аффикс, образующий отглагольные имена, судя по немногочисленному материалу, абстрактного значения [Gabain, 1950, s. 75; Древнетюркский словарь, 1968, с. 655; Clauson, 1972, p. 462: tutyak; Кононов, 1980, с. 91]. Возможно, вслед за сэром Дж. Клосоном его следует считать формой аффикса $-j O K(-j U K ?)$. Он известен только с периода древнеуйгурских буддийских текстов, где обозначает прошедшее очевидное время (претерит), в других текстах (манихейских, караханидско-уйгурских) - это причастие совершенного действия или имя с абстрактным значением, в отдельных случаях, когда субстантивируется, обозначает объект действия [Erdal, 2004, p. 22, 74, 240, 266-268, 300-301]. В текстах на брахми морфема -jOK (-jUK?) употребляется после широкого /ä/, что может быть фактором, влияющим на делабиализацию аффиксального гласного, поскольку в южно-сибирских тюркских языках получила развитие форма - $\check{X K}$ [Erdal, 2004, p. 300, note 489] (см. иначе: [Сравнительно-историческая грамматика, 1988, с. 362-367]). В нашем 
случае чтение исходной формы слова должно выглядеть скорее как *čökjök, хотя это не отражено в написании, поскольку исходя из употребления слогового знака $/ \ddot{k} \mathrm{k} / \sim / \mathrm{k}^{\ddot{v}} /$, подразумевающего огубленный гласный в соседстве со смычным, его можно было бы ожидать и в аффиксе. Употребление слова с̌ökä 'коленопреклонение' [Древнетюркский словарь, 1968, c. 154-155; Clauson, 1972, p. 414], повидимому, заставляет предполагать, что идентифицированная нами форма должна быть не идентичной ему с точки зрения лексического значения, а обозначать, скорее, объект действия глагола.

В этом случае здесь допустимо читать čökjäk-i-n и видеть + Хn - показатель винительного падежа, добавленный к посессивной форме 3 лица ед. ч. [Erdal, 2004, p. 185-186; Кормушин, 2008, с. 188] (ср. ниже enči-g). В контексте, однако, остается неясным, с кем связана форма посессива - с собственно субъектом действия, который обозначен субстантивированным причастием (ägidmiś), или следующим словом, возможно, являющимся частью конструкции из двух существительных, выступающей при предлагаемой интерпретации как однородное сложное дополнение.

Точно также здесь можно видеть показатель инструментального (орудно-совместного) падежа, имевшего форму $+(X) n$ (в орхонских и древнеуйгурских буддийских текстах) или $+(I) n$ в манихейских текстах [Erdal, 2004, p. 175-177]. Между тем, и показатель винительного падежа для 3 лица в древнетюркских текстах никогда не подвергался лабиализации [Erdal, 2004, p. 186]. В нашем случае мы не можем быть уверены в качестве аффиксального гласного, однако, если он имел огубленный характер, читалось бы *čökjökün.
Ввиду неопределенности мы сохраняем условное *čökjäkin. При такой трактовке посредством инструментального падежа может быть отражено значение образа действия [Erdal, 2004, p. 378-379].

är-im: är 'муж', 'мужчина', $++(X) m$ - аффикс принадлежности 1 лица ед. ч. Никакие иные чтения вроде формально допустимого *čökj(ä)k (e)n(ä)r(i)m не могут получить обоснования с синтаксической точки зрения. Предпочтительнее не интерпретировать второй знак (№ 15) как показатель посессива, поскольку, например, в Таласских надписях и надписях Кочкорской долины для обозначения аффикса принадлежности 1 лица, как единственного, так и множественного числа, используется «канонический» знак для обозначения /m/ (№ 3) [Alimov, 2014, s. 27].

enči-g: наличие отдельно выписанных согласных $n^{2}$ и $\check{c}$ должно подразумевать гласный между ними, поскольку для сочетания этих звуков есть специальный знак $\underline{n c}$, если только не предполагать здесь какоето исключение, которое предположительно можно читать в енисейской надписи Туба I (Е 35, стк. 2) [Y1ldırım et al, 2013, s. 98-99] и алтайской Ялбак-Таш XVIII [Кызласов, 2003, c. 67]. Это допущение предоставляет, по-видимому, единственную возможность интерпретировать данное слово. Это должно быть отыменное имя деятеля, образованное при помощи аффикса $+\check{c} I$, с показателем винительного падежа $+(X) G$, которое, повидимому, согласуется с отмеченным выше глаголом je:r-. Замечания о слове en см. выше.

Таким образом, мы можем видеть здесь определительную конструкцию $\ddot{r} r$-im enči-g, выступающую целиком в качестве дополнения, од- 
Рогожсинский A.E., Тишин B.B. Древнетюркские рунические надписи и их археологические...

нородного в этой функции предыдущему слову. Использование в препозиционном определении лексемы с показателем принадлежности широко известно в памятниках древнетюркской рунической письменности [Кононов, 1980, с. 214]. Формально är-im может выступать в роли подлежащего, а еnci-g - в качестве дополнения. Однако такая интерпретация предполагает значительные синтаксические трудности.

Замечания к графическому фонду. С позиций палеографии примечательно употребление в одном тексте двух вариантов написания графемы с фонемным значением $/ \mathrm{m} /$, что, в частности, известно, например, для Первого и Второго Таласских памятников [Батманов, 1971, с. 9, рис. 1, 2, с. 10; Y1ldirım et al, 2013, s. 284; Alimov, 2014, s. 208; Alimov, 2017, s. 135]. С этой территориальной группой памятников древнетюркской рунической письменности надпись Кулжабасы II сближает именно написание $/ \mathrm{m} /$, но вместе с тем не характерныйдляэтойгруппыслоговый знак $/ \ddot{k} / \sim / \mathrm{k}^{\ddot{v}}$, направленный влево, что зафиксировано только в надписи Ак-Олён [Alimov, 2014, s. 26, No 37, s. 228, 229]. Наиболее выделяющейся чертой является форма очертаний / $\mathrm{r}^{2} /$, находящая ближайшую параллель также в надписях из местности АкОлён [Alimov, 2014, s. 26, No. 30].

Написание знака в форме «крыши»/'́s/ также роднит надпись с памятниками енисейского бассейна, Алтая и Таласской долины. Употребление «традиционной» $/ \mathrm{m} /$ в ее начертаниях находит параллели опять же в надписях группы Ак-Олён [Alimov, 2014, s. 24, No. 8]. Для ряда енисейских памятников также характерно употребление двух знаков, содержащих фонему /m/ (ср.: [Alimov, 2014, s. 21]), один из которых, употребляющийся наряду с традиционным монозвуковым знаком, обозначает, возможно, слоговое сочетание $/ \mathrm{mI} / \sim / \mathrm{Im} /$ или / mA/ /Am/ [Кызласов, 1994, с. 120121, табл. XXIII: В].

Интересными чертами рассмотренной надписи являются редкое левонаправленное начертание /g/ [Baсильев, 1983 , с. 110 , табл. 10 , стк. 2 , 11 , с. 111 , табл. 10 , стк. 15], а также наличие двух разных, зеркально противоположных начертаний $/ \mathrm{n}^{2} \%$.

Замечания к датировке и атрибуции. Если предложенное нами прочтение надписи верно, следует отметить ее возможный религиозный подтекст. Читаемый текст является синтаксически очень сложным, перегруженным глагольными формами. Одним из важнейших моментов является наблюдаемое употребление субстантивированной формы причастия прошедшего времени на -mǏ́, выступающего как подлежащее, и употребление глагольной формы будущего времени на -GAj. Последнее позволяет лишь формально охарактеризовать надпись как более позднюю в сравнении с орхонскими памятниками.

Если правильно определен аффикс -jAK, выступающий как алломорф *-jUK, здесь можно видеть либо отражение диалектных особенностей автора надписи, либо скорее трактовать обусловленность такого написания вариативностью самого произношения -jOK $\sim-j U K$, т.е. подразумевающего только огубленные гласные, не получившие графического обозначения в связи с отсутствием в тюркских языках самого варианта с широким неогубленным гласным.

\section{Выводы}

Археологическое окружение рунических надписей из Кулжабасы 
дает повод предположить, что обе они связаны своим местонахождением с долговременными средневековыми стоянками, отмеченными парами однотипных тамг и серией петроглифов в долине 3 , которые относятся к числу «престижных» символовмаркеров. Однако функциональную и временную связь всех компонентов нельзя принять безоговорочно. Если последовательность нанесения на скалу тамги № 1, а затем трех рунических строк Кулжабасы I признать очевидной, то создание тамги можно рассматривать как terminus post quem для надписи, или считать оба события одновременными. В таком случае принадлежность типа тамги №№ 1 и 4 карлукскому объединению, как сказано выше, может служить прямым основанием для датировки рунической надписи в долине 3 не ранее второй половины VIII в. или даже IX-X вв., принимая во внимание находки караханидского облика из близлежащей стоянки. К сожалению, временная связь надписи Кулжабасы II с атрибутированными тамгами у стоянки в долине 14 вероятна, но остается гипотетической.

\section{***}

P. Алимов, указав на близость графического фонда памятников древнетюркской рунической письменности Восточного и ЮгоВосточного Казахстана с памятниками на территории Кыргызстана, для последних отмечал наиболее тесную связь с надписями Алтая, откуда они и должны были распространяться на Тянь-Шань. В свою очередь, графический фонд памятников Алтая пополнялся из двух источников: с территории Енисейской долины и Монголии [Alimov, 2014, s. 22-23]. При этом надписи из местности Ак-Олён гораздо ближе примыкают к енисей- ским надписям [Alimov, 2014, s. 18]. Уточнение датировки надписей Таласской долины оказалось возможным, по мнению С.Г. Кляшторного, благодаря привлечению археологических данных [Кляшторный, 2003, c. 289-293; 2006, с. 349-354], в то время как определенные выводы о времени создания надписей Кочкорской долины и местности Ак-Олён сделаны на основании атрибуции сопровождающей их «омегообразной» тамги, связываемой некоторыми исследователями с племенами тюргешского круга [Alimov, 2014, s. 34-41]. Впрочем, такое отождествление является дискуссионным.

Если принять за нижнюю хронологическую границу времени создания надписей Таласской долины период первой половины VIII в., это даст ориентиры для определения времени формирования графического фонда лишь одного из очагов распространения памятников древнетюркской рунической письменности на территории современных Кыргызстана и Казахстана. Учитывая генетическую близость, но не идентичность в палеографическом отношении таласским надписям текстов Кочкорской долины, местности Ак-Олён и Западного Жетысу, а также памятников с территории Алтая и долины р. Енисей, возможно предположить, что в эти районы древнетюркская письменная традиция проникала сравнительно позднее и, вероятно, с разных направлений - с Таласа и Алтая, - ввиду чего сам графический фонд формировался под влиянием нескольких традиций. С другой стороны, гораздо более логичным кажется, что именно Таласская долина должна рассматриваться здесь как крайняя западная точка распространения древнетюркского рунического письма, куда оно 
Рогожсинский A.E., Тишин B.B. Древнетюркские рунические надписи и их археологические...

должно было проникать как раз через территорию Западного Прииссыккулья (Кочкорская долина, Ак-Олён) и Шу-Илейского междуречья, соответственно с восточного направления. Это кажется более логичным, учитывая именно определенную самобытность графического фонда таласских надписей по сравнению с памятниками других географических групп, имеющих между собой гораздо больше общего. Это отнюдь не означает, что памятники одних групп обязательно должны быть признаны более ранними, других - более поздними относительно друг друга. Такой под- ход слишком упрощал бы реальную ситуацию, допускающую сосуществование на протяжении какого-то времени нескольких локальных традиций, графические особенности которых формировались уже под влиянием факторов, непосредственно связанных с каждой из местностей. Сказать что-то определенное можно будет только при расширении источниковой базы - как за счет качественной обработки материала уже известных надписей, так и за счет введения в научный оборот новых находок.

\section{ЛИТЕРАТУРА}

1. Батманов И.А. Таласские памятники древнетюркской письменности. Фрунзе: Илим, 1971. 66 с.

2. Базылхан Н. Древнетюркские надписи с территории Казахстана // Российская тюркология. 2013. № 2 (9). С. 95-105.

3. Базылхан Н., Железняков Б.А., Хермани Л., Жамбулатов К. Находка памятника древнетюркской письменности в горах Кульжабасы (предварительное чтение) // Мәдени ықпалдастық және өркениеттер бірлігі: V халықаралық түркология конгресі баяндамалар жинағы. Түркістан: Қ.А. Ясауи атындағы халықаралық Қазақтүрік университеті, 2013. Б. 664-669.

4. Борисенко А.Ю., Худяков Ю.С. Типология бронзовых бляшек с изображением всадников и лошадей в торевтике тюркских кочевников Центральной Азии раннего средневековья // Изучение историко-культурного наследия народов Южной Сибири: сб. научн. тр. Под ред. В.И. Соёнова, В.П. Ойношева. Горно-Алтайск: Агентство по историко-культурному наследию, 2007. Вып. 6. С. 75-98.

5. Васильев Д.Д. Графический фонд памятников тюркской рунической письменности Азиатского ареала (опыт систематизации). М.: «Наука», 1983. 146 с.

6. Гаврилова A.A. Могильник Кудыргэ как источник по истории алтайских племён. М.-Л.: «Наука», 1965. 145 с.

7. Гуркин С.В. Кыпчаки и кимаки в IX - первой трети XI вв. // Донская археология. 2001. № 3-4. С. 24-37.

8. Древнетюркский словарь / под ред. В.М. Наделяева, Д.М. Насилова, Э.Р. Тенишева, А.М. Щербака. Л.: «Наука», 1969. XXXVIII. 714 с.

9. Ермоленко Л.Н., Курманкулов Ж.К. Проблема иконографических истоков половецкой скульптуры и особенное кыпчакское изваяние из урочища Кызлы // Известия НАН РК. Сер. обществ. наук. 2013. № 3 (289). С. 155-164.

10. Железняков Б.А., Базылхан Н., Херманн Л. Новый памятник древнетюркской письменности в горах Кулжабасы (предварительное чтение) // Известия НАН РК. Сер. обществ. и гум. наук. 2013. Вып. 3(289). С. 147-155.

11. Касанов 3.И., Кан Г.В., Рогожинский А.Е. Символы тюркской эпохи. Алматы: TOO «Service Press», 2017. 304 c. 
12. Киргизско-русский словарь (Кыргызча-орусча сөздүк): в двух кн. / сост. К.К. Юдахин. Фрунзе: Сов. энциклопедия, 1985. Кн. 2: Л-Я. 480 с.

13. Кляшторный С.Г. История Центральной Азии и памятники рунического письма. СПб.: Филологический факультет СПбГУ, 2003. 560 с.

14. Кляшторный С.Г. Памятники древнетюркской письменности и этнокультурная история Центральной Азии. СПб.: «Наука», 2006. 591 с.

15. Кононов А.Н. Грамматика языка тюркских рунических памятников VIIIX вв. Л.: «Наука», 1980. 170 с.

16. Кормушин И.В. Тюркские енисейские эпитафии. Тексты и исследования. М.: «Наука», 1997. 303 с.

17. Кормушин И.В. Тюркские енисейские эпитафии: грамматика, текстология. М.: «Наука», 2008. 342 с.

18. Кубарев Г.В. Раннесредневековые тамги Калбак-Таша I и их исторический контекст // Значение природного и культурного наследия в современном обществе. Горно-Алтайск, 2018. С. 33-39.

19. Кызлласов И.Л. Рунические письменности евразийских степей. М.: Вост. лит-ра, 1994. 327 с.

20. Кызласов И.Л. Новости тюркской рунологии. М.: Гуманитарий, 2003. Вып. 1. Енисейские надписи на горе Ялбак-таш (Горный Алтай). 112 с.

21. Кызласов И.Л. Раннесредневековая эпиграфика Казахстана и Кыргызстана: проблема датировки, происхождения и принадлежности таласского рунического письма (в кратком изложении) // Историко-культурное наследие и современная культура: сб. матер. междунар. научн.-практ. семинара (г. Алматы, 30 ноября 2012). Алматы: «Service Press», 2012. C. 40-44.

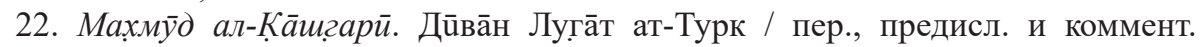
3.-А.М. Ауэзовой; индексы составлены Р. Эрмерсом. Алматы: Дайк-Пресс, 2005. $1288 \mathrm{c}$.

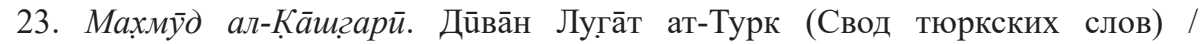
пер. с арабск. А.Р. Рустамова; под ред. И.В. Кормушина; прим. И.В. Кормушина, Е.А. Поцелуевского, А.Р. Рустамова. М.: Вост. лит-ра РАН, 2010. Т. 1. 461 с.

24. Радлов В.В. Опыт словаря тюркских наречий. СПб.: Тип. Имп. АН, 1905. Т III. Ч. 1. Стб. 1-1260.

25. Радлов В.В. Опыт словаря тюркских наречий. СПб.: Тип. Имп. АН, 1911. T. IV. Ч. 1. Стб. 1-1116, 107 с.

26. Рогожинский A.E. Новые находки памятников древнетюркской эпиграфики и монументального искусства на юге и востоке Казахстана // Роль номадов в формировании культурного наследия Казахстана. Научные чтения памяти Н.Э. Масанова: сб. матер. междунар. научн. конф. Алматы: Print-S, 2010. C. 329-344.

27. Рогожинский A.E. Знаки собственности и власти древних и средневековых обитателей Казахской степи // Археологическое наследие Сибири и Центральной Азии (проблемы интерпретации и сохранения): матер. междунар. конф. Под ред. В.В. Боброва. Кемерово, 2016. С. 53-63.

28. Рогожинский А.Е., Кызласов И.Л. Руническая надпись ущелья Жаксылыксай (Семиречье) // Маргулановские чтения - 2011 (г. Астана, 20-22 апреля 2011). Астана, 2011. С. 330-334.

29. Сала Р., Деом Ж.-М. Наскальные изображения Южного Казахстана. Алматы: «Лаборатория геоархеологии», 2005. 150 с.

30. Севортян Э.В. Этимологический словарь тюркских языков (Общетюркские и межтюркские основы на гласные). М.: «Наука», 1974. 767 с.

31. Сравнительно-историческая грамматика тюркских языков. Пратюркский язык-основа. Картина мира пратюркского этноса по данным языка / Отв. ред. Э.Р. Тенишев, А.В. Дыбо. М.: «Наука», 2006. 908 с.

32. Тишин В.В. Древнетюркские рунические надписи из Восточного и ЮгоВосточного Казахстана (Койтубек, Тамгалы, Актерек, Кулжабасы I, Кулжабасы II) // 
Рогожинский A.E., Тишин B.B. Древнетюркские рунические надписи и их археологические...

Историческая мозаика Евразии: сб. ст. к 70-летию Д.Д. Васильева / сост. Т.А. Аникеева, А.Д. Васильев, О.М. Курникова, Т.А. Филиппова. М.: ПРОБЕЛ-2000, 2017. С. 244-259.

33. Тишин B.B. К прочтению древнетюркской рунической надписи Кулжабасы I из Жетысу // Комплексный подход в изучении природы, общества и человека: сб. докл. междунар. научн. конф., посвящ. 110-летию со дня рождения выдающегося ученого-этнолога С.М. Абрамзона (г. Бишкек, 16-17 мая 2015). Отв. ред. М.А. ЗенькоНемчинова, С.С. Иванов Бишкек, 2015. С. 133-138.

34. Тишин B.B. Некоторые вопросы изучения тамг кочевников Центральной Азии древнетюркского времени // Труды Института востоковедения РАН. 2018. Вып. 7. Тюркские кочевники в Азии и Европе (Цивилизационные аспекты истории и культуры). С. 101-113.

35. Этимологический словарь тюркских языков: Общетюркские и межтюркские лексические основы на буквы «К» $(\sim\langle\Gamma »)$ и «Қ» $(\sim\langle Қ » \sim\langle К »)$. Вып. первый. М.: «Языки русской культуры», 1997. 368 с.

36. Этимологический словарь тюркских языков: Общетюркские и межтюркские лексические основы на буквы «К» ( «Г») и «Қ» ( «Қ» «К»). М.: «Индрик», 2000. Вып. второй. Отв. ред. Г.Ф. Благова. 261 с.

37. Этимологический словарь тюркских языков. Общетюркские и межтюркские основы на буквы «Л», «М», «Н», «П», «С»/ отв. ред. Г.Ф. Благова. М.: Восточная литература РАН, 2003. 446 c.

38. Alimov R. Koçkor'daki Türgeş Yazıtları // İstanbul Üniversitesi Sosyal Bilimler Dergisi. 2003. Sayı 1. S. 13-43.

39. Alimov R. Tanrı Dağı Yazıtları. Eski Türk Runik Yazıtları Üzerine Bir İnceleme. Konya: Kömen Yayınları, 2014. (5), 262 s.

40. Alimov R. Talas Yazıtları: İşaret Kadrosuyla İlgili Bazı Düzeltmeler (2. Talas Yazıtı Örneğinde) // Türk Dili Araştırmaları Yıllı̆̆ı Belleten. 2017. Cilt. 65. Sayı 1. S. '129-144.

41. Bazilkhan N. Kazakistan'da Bulunan Göktürk Yazıtları Hakkında // Uluslararası Türkçe Edebiyat Kültür Eğitim Dergisi. 2014. Sayı 3/2. S. 1-12.

42. Clauson G. An Etymological Dictionary of Pre-Thirteenth-Century Turkish. Oxford: Clarendon Press, 1972. XLVIII, 989 p.

43. Erdal M. Old Turkic Word Formation: A Functional Approach to the Lexicon. Wiesbaben: Harrassowitz, 1991 (Turcologica. Bd. 7). Vol. I-II. XIV, 874 p.

44. Erdal M. A Grammar of Old Turkic. Leiden; Boston: Brill, 2004 (Handbook of Oriental Studies, Section 8 Uralic \& Central Asia. Vol. 3). XII, 575 p.

45. Gabain A. (von) Alttürkische Grammatik. Mit Bibliographie, Lesestücken und Wörterverzeichnis, auch Neutürkisch. Mit vier Schrifttafeln und sieben Schriftproben.

2. verbesserte Auflage. Leipzig: Otto Harrassowitz, 1950. XVIII, 357, [18] S.

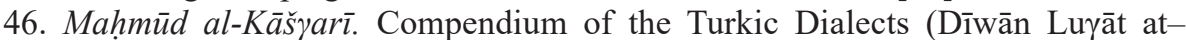
Turk) / ed. and transl. with Introduction and Indices by R. Dankoff in collaboration with J. Kelly. Cambridge, Mass.: Harvard University Office of the University Publisher, 1982. Pt. I. XI, 416 p.

47. Mert A. Kutadgu Bilig Nüshalarının Eskicillik Açısından Karşılaştırılması // BİLİG Türk Dünyası Sosyal Bilimler Dergisi. 2017. Sayı 80. S. 179-215.

48. Rybatzki V. Die Personennamen und Titel der Mittelmongolischen Dokumente. Eine lexikalische Untersuchung. Helsinki: Yliopistopaino Oy, 2006. XXXV, 841 S.

49. Sala R., Deom J.-M. Spatial analysis of the Kuljabasy Archaeological Complex // Древности Жетысу. Памятники археологии Жамбылского района. Алматы: TOO «Litera», 2016. C. 73-87.

50. Tekin T. A Grammar of Orkhon Turkic. Bloomington; The Hague: Mouton \& Co, 1968. $419 \mathrm{p}$. 
51. Tuna O.N. Eski Doğu Türk Yazısında Kullanılan Ligatürler ve Bunlarla İlgili Bazı meseleler Hakkında // Türk Dili Araştırmaları Yıllı̆̆ı, Belleten 1990. Ankara, 1994. S. 207-222.

52. Yıldırım F., Aydın E., Alimov R. Yenisey-Kirgizistan Yazıtları ve Irk Bitig. Ankara: BilgeSu, 2013. $512 \mathrm{~s}$.

\section{Сведения об авторах:}

Рогожинский Алексей Евгеньевич - кандидат исторических наук, ведущий научный сотрудник, Научно-реставрационная лаборатория ТОО «Остров Крым», (г. Алматы, Казахстан); alexeyro@hotmail.com

Тишин Владимир Владимирович - кандидат исторических наук, старший научный сотрудник, Институт монголоведения, буддологии и тибетологии РАН (г. УланУдэ, Республика Бурятия, Российская Федерация); tihij-511@mail.ru

\section{КӨНЕ ТУРКІ РУНИКАЛЫҚ ЖАЗУЛАРЫ ЖӘНЕ ОЛАРДЫН ҚҰЛЖАБАСЫ ТАУЫНДАҒЫ АРХЕОЛОГИЯЛЫҚ МӘНМӘТІНДЕРІ}

\section{А.Е. Рогожинский, В.В. Тишин}

Мақалада Құлжабасы I және Құлжабасы II көне түркі руникалық жазуларын жаңа тұрғыда оқудың талпынысы беріледі және жинақталған мәліметтерді сараптаудың негізінде оларды мерзімдеу мен белгілеудің мүмкіндіктерді талқыланады. Авторлар жазулардың ерекшеліктері мен оларды табудың археологиялық мәнмәтінін сараптайды. Құлжабасы жазуларының графикалық қорларының көне түркі жазба ескерткіштерінің жалпы мәнмәтіндегі азиаттық таралу аймағындағы ерекшеліктерін көрсетуге ұмтылыс байқалады. Құлжабасы тауларының археологиялық ландшафттының құрамындағы екі руникалық жазбалар ортағасырлық ескерткіштердің оқшауланған ауданында (көшпенділердің қыстауларында, обаларда, мүсіндері бар жерлеу қоршауларында, «беделді» тақырыптардың петроглифтері), біртипті белгілермен (тамға) тасқа салынған бейнелермен белгіленген ірі қоныстарға жақын болуымен ерекшеленеді. Құлжабасы I археологиялық мәнмәтіні жазуды VIII ғ. екінші жартысынан кейін немеce IX-X ғғ. деп мерзімдеуге мүмкіндік береді. Қарлұқтардың тайпалық бірлестігінің бір типті белгілерімен бірегейлілікке жатқызылады деген ұйғарымға келеді.

Түйін сөздер: археология, Жетісу, көне түркі руникалық жазулары, археологиялық мәнмәтін, тамға, петроглифтер, қарлұқтар

\section{OLD TURKIC RUNIC INSCRIPTIONS AND ITS ARCHAEOLOGICAL CON- TEXTS IN THE KULZHABASY MOUNTAINS}

\section{A.E. Rogozhinskiy, V.V. Tishin}

This article proposes a new translation of two Old Turkic runic inscriptions Kuljabasy I and Kuljabasy II, and discusses some possibilities of their dating and attribution based on a comprehensive analysis of the available material. The analysis is based not only on individual characteristics of the inscriptions but also takes into consideration the archaeological context of their location. The article aims to identify typical graphical features of Kuljabasy inscriptions, in the general context of Old Turkic runic writing monuments of the Asian area. Within the archaeological landscape of the Kuljabasy Mountains, both runic inscriptions are localized in two separate areas of concentration of medieval monuments (such as winter camps of nomads, burial grounds, ritual fences with statues, petroglyphs of "prestigious" themes), near large settlements marked with petroglyphs of similar signs (tamga). The archaeological context of Kuljabasy I allows dating the inscription no earlier than the second half of the 8th century or 9-10th centuries. Based on presented analysis it can be assumed that the identity signs of the same type (tamga № 1 and 4) belong to the Karluk tribal association.

Keywords: archaeology, Jetysu, Old Turkic runic inscriptions, archaeological context, tamga, petroglyphs, Karluk 
Рогожинский A.E., Тишин B.B. Древнетюркские рунические надписи и их археологические...

\section{REFERENCES}

1. Batmanov, I. A. 1971. Talasskie pamjatniki drevnetjurkskoj pis'mennosti (Talas monuments of ancient Turkic writing). Frunze: Ilim (in Russian).

2. Bazylhan, N. 2013. In Rossijskaja tjurkologija (Russian Turkology), 2 (9), 95-105 (in Russian).

3. Bazylhan, N., Zheleznjakov, B. A., Hermani, L., Jambulatov, K. 2013. In V International Congress of Turkology. Turkestan: Akhmet Yassawi International Kazakh-Turkish University Publ., 664-669 (in Russian).

4. Borisenko, A. Ju., Hudjakov, Ju. S. 2007. In Soyonov, V. I., Oynoshev, V.P. (ed.). Izuchenie istoriko-kul'turnogo nasledija narodov Juzhnoj Sibiri (The study of the historical and cultural heritage of the peoples of Southern Siberia), 6. Gorno-Altajsk, 75-98 (in Russian).

5. Vasil'ev, D. D. 1983. Graficheskij fond pamjatnikov tjurkskoj runicheskoj pis'mennosti Aziatskogo areala (opyt sistematizacii) (Graphic fund of monuments of the Turkic runic writing of the Asian area (experience of systematization). Moscow: «Nauka» (in Russian).

6. Gavrilova, A. A. 1965. Mogil'nik Kudyrge kak istochnik po istorii altajskih plemyon (Burial Kudyrge as a source on the history of the Altay tribes). Moscow-Leningrad: «Nauka» (in Russian).

7. Gurkin, S. V. 2001. In Donskaja arheologija (Don archaeology), 3-4, 24-37.

8. Drevnetjurkskij slovar' (Ancient Turkic dictionary). 1969. Nadeljaeva, V. M., Nasilova, D. M., Tenisheva, Je. R., Shherbaka, A. M. (ed.). Leningrad: «Nauka», XXXVIII (in Russian).

9. Ermolenko, L. N., Kurmankulov, J. K. 2013. In Izvestija NAN RK. Ser. obshhestv. nauk. (Proceedings of the National Academy of Sciences. Social Science Series), 3 (289), 155-164 (in Russian).

10. Zheleznjakov, B. A., Bazylhan, N., Hermann, L. 2013. In Izvestija NAN RK. Ser. obshch. i gum. nauk (News of the National Academy of Sciences of the Republic of Kazakhstan. A series of social sciences and humanities), 3 (289), 147-155 (in Russian).

11. Kasanov, Z. I., Kan, G. V., Rogozhinskiy, A. E. 2017. Simvoly tjurkskoj jepohi (Symbols of the Turkic era). Almaty: TOO «Service Press» (in Russian).

12. Kirgizsko-russkij slovar' (Kyrgyz-Russian Dictionary). 1985. Frunze: Sov. Jenciklopedija (in Russian).

13. Klyashtornyi, S. G. 2003. Istorija Central'noj Azii i pamjatniki runicheskogo pis'ma (History of Central Asia and the monuments of runic letters). Saint Petersburg: Philology faculty Saint Petersburg State University (in Russian).

14. Klyashtornyi, S. G. 2006. Pamjatniki drevnetjurkskoj pis'mennosti $i$ jetnokul 'turnaja istorija Central'noj Azii (Monuments of ancient Turkic writing and the ethnocultural history of Central Asia). Saint Petersburg: «Nauka» (in Russian).

15. Kononov, A. N. 1980. Grammatika jazyka tjurkskih runicheskih pamjatnikov VII-IX vv. (The grammar of the language of Turkic runic monuments of the VIIth-IXth centuries). Leningrad: «Nauka» Publ. (in Russian).

16. Kormushin, I. V. 1997. Tjurkskie enisejskie jepitafii. Teksty i issledovanija Turkic Yenisei epitaphs. Texts and studies), Moscow: «Nauka» Publ. (in Russian).

17. Kormushin, I. V. 2008. Tjurkskie enisejskie jepitafii: grammatika, tekstologija (Turkic Yenisei epitaphs: grammar, textual). Moscow: «Nauka» Publ. (in Russian).

18. Kubarev, G. V. 2018. In Znachenie prirodnogo i kul'turnogo nasledija v sovremennom obshhestve (The value of natural and cultural heritage in modern society). GornoAltaysk, 33-39.

19. Kyzlasov, I. L. 1994. Runicheskie pis'mennosti evrazijskih stepej (Runic writing Eurasian steppes), Moscow: Vost. lit-ra Publ. (in Russian).

20. Kyzlasov, I. L. 2003. Novosti tyurkskoj runologii (News of Turkic Runology), 1 (in Russian). 
21. Kyzlasov, I. L. 2012. In Istoriko-kul'turnoe nasledie i sovremennaja kul'tura (Historical and cultural heritage and modern culture). Almaty: Service Press, 40-44 (in Russian).

22. Maḥmȳd al-Ḳāshgarū. 2005. Dūvān Lugāat at-Turk. Aujezova, Z.-A. M. (per., predisl. i komment.); Jermersom, R. (indeksy), Almaty: Dajk-Press Publ.

23. Mạ̣mȳd al-Kāashgarū. 2010. Dūvān Lugāat at-Turk (Svod tjurkskih slov) Rustamova, A. R. (per. s arabsk.); Kormushina, I. V. (red.); Kormushina, I. V., Poceluevskogo, E. A., Rustamova, A. R. (prim.). Moscow: Vost. lit-ra RAN, 1 (in Russian).

24. Radlov, V. V. 1905. Opyt slovarja tjurkskih narechij (Experience dictionary of Turkic dialects), III, Ch. Saint Petersburg: Tip. Imp. Akad. nauk, 1-1260.

25. Radlov, V. V. 1911. Opyt slovarja tjurkskih narechij (Experience dictionary of Turkic dialects), IV, Ch. 1, Saint Petersburg: Tip. Imp. Akad. nauk, 1-1116 (in Russian).

26. Rogozhinskiy, A. E. 2010. In Rol' nomadov v formirovanii kul 'turnogo nasledija Kazahstana. Nauchnye chtenija pamjati N. Je. Masanova (The role of nomads in shaping the cultural heritage of Kazakhstan. Scientific readings in memory of N.E. Masanov). Almaty: Print-S Publ., 329-344 (in Russian).

27. Rogozhinskiy, A. E. 2016. In Bobrov, V. V. (ed.). Arheologicheskoe nasledie Sibiri i Central'noj Azii (problemy interpretacii i sohranenija) (Archaeological heritage of Siberia and Central Asia (problems of interpretation and preservation). Kemerovo, 53-63 (in Russian).

28. Rogozhinskiy, A. E., Kyzlasov, I. L. 2011. In Margulanovskie chtenija - 2011 (Margulan Readings - 2011). Astana, 330-334 (in Russian).

29. Sala, R., Deom, Zh.-M. 2005. Naskal'nye izobrazhenija Juzhnogo Kazahstana (Rock paintings of South Kazakhstan). Almaty: «Laboratorija geoarheologii» (in Russian).

30. Sevortyan, Je. V. 1974. Jetimologicheskij slovar'tjurkskih jazykov (Obshhetjurkskie i mezhtjurkskie osnovy na glasnye) (Etymological dictionary of Turkic languages (common Turkic and inter-Turkic bases for vowels). Moscow: «Nauka» Publ. (in Russian).

31. Sravnitel'no-istoricheskaja grammatika tjurkskih jazykov. Pratjurkskij jazykosnova. Kartina mira pratjurkskogo jetnosa po dannym jazyka (Comparative historical grammar of Turkic languages. Pra-Türkic language basis. Picture of the world of the praTürkic ethnos according to the language). 2006. Tenishev, Je. R., Dybo, A. V. (ed.). Moscow: «Nauka» Publ. (in Russian).

32. Tishin, V. V. 2015. In Zen'ko-Nemchinova, M. A., Ivanov, S. S. (ed.). Kompleksnyj podhod $v$ izuchenii prirody, obshhestva i cheloveka (An integrated approach to the study of nature, society and man). Bishkek, 133-138 (in Russian).

33. Tishin, V. V. 2017. In Anikeeva, T. A., Vasil'ev, A. D., Kurnikova, O. M., Filippova, T. A. (sost.). Istoricheskaja mozaika Evrazii (Historical mosaic of Eurasia). Moscow: PROBEL-2000, 244-259 (in Russian).

34. Tishin, V. V. 2018. In Trudy Instituta vostokovedenija RAN (Proceedings of the Institute of Oriental Studies RAS), 7, 101-113 (in Russian).

35. Jetimologicheskij slovar' tjurkskih jazykov: Obshhetjurkskie i mezhtjurkskie leksicheskie osnovy na bukvy «K» ( «G») $i$ «K» ( «K» «K»). Vypusk pervyj (Etymological dictionary of Turkic languages: General Turkic and inter-Turkic lexical bases on the

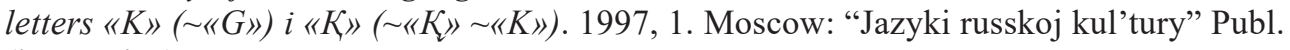
(in Russian).

36. Jetimologicheskij slovar'tjurkskih jazykov: Obshhetjurkskie i mezhtjurkskie leksicheskie osnovy na bukvy «K» ( $\langle G ») i\langle K »(\sim\langle\zeta » \sim\langle K »)$ (Etymological dictionary of Turkic languages: General Turkic and inter-Turkic lexical bases on the letters " $K$ " ( "G") and "K» ( «» «K»). 2000. Moscow: "Indrik" Publ., 2 (in Russian).

37. Jetimologicheskij slovar' tjurkskih jazykov. Obshhetjurkskie i mezhtjurkskie osnovy na bukvy «L», «M», «N», «P», «S») (Etymological dictionary of Turkic languages: General Turkic and inter-Turkic lexical bases on the letters $\langle L »,\langle M »,\langle N »$, «P», «S»). 2003. Blagova, G. F. (ed.). Moscow: Vostochnaja literatura RAN (in Russian). 
Рогожинский A.E., Тишин B.B. Древнетюркские рунические надписи и их археологические... Turkish).

38. Alimov, R. 2003. In İstanbul Üniversitesi Sosyal Bilimler Dergisi, 1, 13-43 (in

39. Alimov, R. 2014. Tanrı Dă̆ı Yazıtları. Eski Türk Runik Yazıtları Üzerine Bir Inceleme. Konya: Kömen Yayınları, 5 (in Turkish).

40. Alimov, R. 2017. In Türk Dili Araştırmaları Yılliğı Belleten, Cilt. 65, Sayı 1, 129-144 (in Turkish).

41. Bazilkhan, N. 2014. In Uluslararası Türkçe Edebiyat Kültür Eğitim Dergisi, 3/2, 1-12 (in Turkish).

42. Clauson, G. 1972. An Etymological Dictionary of Pre-Thirteenth-Century Turkish. Oxford: Clarendon Press, XLVIII (in English).

43. Erdal, M. 1991. Old Turkic Word Formation: A Functional Approach to the Lexicon. Wiesbaben: Harrassowitz (Turcologica. Bd. 7), I-II, XIV (in English).

44. Erdal, M. 2004. A Grammar of Old Turkic. Leiden; Boston: Brill (Handbook of Oriental Studies, Section 8 Uralic \& Central Asia. Vol. 3), XII.

45. Gabain, A. (von) 1950. Alttürkische Grammatik. Mit Bibliographie, Lesestücken und Wörterverzeichnis, auch Neutürkisch. Mit vier Schrifttafeln und sieben Schriftproben. 2. verbesserte Auflage. Leipzig: Otto Harrassowitz, XVIII, 357.

46. Maḥmūd al-Kāšyarī. 1982. Compendium of the Turkic Dialects (Dīwān Luүāt at-Turk) / ed. and transl. with Introduction and Indices by R. Dankoff in collaboration with J. Kelly. Cambridge, Mass.: Harvard University Office of the University Publisher, I. XI.

47. Mert, A. 2017. In BíliG Türk Dünyası Sosyal Bilimler Dergisi. 2017, 80, 179215 (in Turkish).

48. Rybatzki, V. 2006. Die Personennamen und Titel der Mittelmongolischen Dokumente. Eine lexikalische Untersuchung. Helsinki: Yliopistopaino Oy, XXXV.

49. Sala, R., Deom, J.-M. 2016. In Antiquities Jetysu. Monuments of archeology of Jambyl region. Алматы: «Litera», 73-87. ton \& Co.

50. Tekin T. 1968. A Grammar of Orkhon Turkic. Bloomington; The Hague: Mou-

51. Tuna O.N. 1994. In Türk Dili Araştırmaları Yıllı̆̆ı, Belleten. Ankara, 207-222 (in Turkish).

52. Yıldırım, F., Aydın, E., Alimov, R. 2013. Yenisey-Kirgizistan Yazıtları ve Irk Bitig. Ankara: BilgeSu (in Turkish).

About the Authors:

Rogozhinskiy Alexey E. Candidate of Historical Sciences, Leading Researcher, Scientific and Restoration Laboratory of "Ostrov Krym" LLP, Almaty, Kazakhstan; alexeyro@hotmail.com

Tishin Vladimir V. Candidate of Historical Sciences, Institute of Mongolian Studies, Buddhology and Tibetology SB RAS, Ulan-Ude, Russia; tihij-511@mail.ru

\footnotetext{
Мүдделер қақтығысы туралы ақпаратты ашу. Авторлар мүдделер қақтығысының жоқтығын мәлімдейді. / Раскрытие информации о конфликте интересов. Авторы заявляют об отсутствии конфликта интересов.

/ Disclosure of conflict of interest information. The authors claims no conflict of interest.

Мақала туралы ақпарат / Информация о статье / Information about the article. Редакцияға түсті / Поступила в редакцию / Entered the editorial office: 15.10.2018.

Рецензенттер мақұлдаған / Одобрено рецензентами / Approved by reviewers: 22.10.2018.

Жариялауға қабылданды / Принята к публикации / Accepted for publication: 25.10.2018.
} 